\title{
Kualitas Fisik Wafer dengan Penambahan Berbagai level Tepung Tapioka serta Tepung Daun Pepaya (Carica papaya L) yang Diolah dengan Teknik Berbeda
}

\section{Romaito Maharani Harahap ${ }^{1}$, Anwar Efendi Harahap ${ }^{2 *}$, Dewi Febrina ${ }^{3}$}

${ }^{1}$ Prodi Peternakan, Fakultas Pertanian dan Peternakan, Universitas Islam Negeri Sultan Syarif Kasim Riau

${ }^{2}$ Prodi Peternakan, Fakultas Pertanian dan Peternakan, Universitas Islam Negeri Sultan Syarif Kasim Riau

${ }^{3}$ Prodi Peternakan, Fakultas Pertanian dan Peternakan, Universitas Islam Negeri Sultan Syarif Kasim Riau

\begin{tabular}{l}
\hline \multicolumn{1}{c}{ ARTIKEL INFO } \\
\hline Sejarah artikel \\
Diterima 27/10/2021 \\
Diterima dalam bentuk revisi 20/12/2021 \\
Diterima dan disetujui 24/12/2021 \\
Tersedia online 31/12/2021 \\
\hline Kata kunci \\
Amoniasi \\
Ransum \\
Kerapatan \\
Tekstur \\
\hline
\end{tabular}

\begin{abstract}
ABSTRAK
Penambahan level tepung tapioka dan tepung daun pepaya (Carica papaya. L) yang diolah mengunakan teknik yang berbeda dalam pembuatan wafer ransum komplit diharapkan mampu memperbaiki kualitas fisik wafer. Tujuan penelitian ini untuk mengetahui kualitas fisik wafer dengan penambahan berbagai level tapioka serta tepung daun pepaya (Carica papaya. $L$ ) yang diolah dengan teknik berbeda. Penelitian ini menggunakan Rancangan Acak Lengkap (RAL) pola faktorial $(2 \times 3)$ dengan 5 ulangan. Faktor A terdiri dari teknik pengolahan daun pepaya yakni, $\mathrm{A} 0=$ Silase daun pepaya; $\mathrm{A} 1$ $=$ Amoniasi daun pepaya. Faktor B terdiri dari B0 = penambahan $0 \%$ tepung tapioka; $\mathrm{B} 1=$ penambahan $5 \%$ tepung tapioka; dan B2 = penambahan $10 \%$ tepung tapioka. Peubah yang diukur adalah warna, aroma, tekstur, daya serap air dan kerapatan. Hasil penelitian ini memperlihatkan tidak terdapat interaksi $(\mathrm{P}>0.05)$ antara teknik pengolahan daun papaya dengan level tepung tapioka yang berbeda terhadap warna, tekstur, aroma, daya serap air dan kerapatan. Daun pepaya yang diolah dengan teknik yang berbeda memberikan berpengaruh nyata $(\mathrm{P}<0,01)$ terhadap warna, tekstur, dan aroma. Penggunaan level tepung tapioka yang berbeda pada pembuatan ransum komplit memberikan berpengaruh nyata $(\mathrm{P}<0,01)$ terhadap warna. Penggunaan amoniasi daun pepaya dalam ransum komplit dengan level tepung tapioka 5\% memberikan hasil terbaik dinilai dari warna yaitu coklat tua dan memberikan skor warna 3,03
\end{abstract}

(C) 2021 Politeknik Pembangunan Pertanian Manokwari

*Email Penulis Korespondensi : harahapa258@gmail.com neniannisaharahap@yahoo.co.id ${ }^{1}$, harahapa258@gmail.com ${ }^{2}$, hanna_suska@yahoo.com ${ }^{3}$ 


\section{ABSTRACT}

Increasing the level of tapioca starch and papaya leaf flour (Carica papaya. L) which are processed using different techniques in making wafers is expected to improve the physical quality of the wafers. The purpose of this study was determine the physical quality of wafers with the addition of various levels of tapioca and papaya leaf flour (Carica papaya. L) which were processed with different techniques. This study used a Complete Randomized Design (RAL) with factorial pattern $(2 \times 3)$ with 5 replication. Factor $A$ consisted of feed processing technique, $A O=$ Silage processing wafers; $A 1=$ Ammonia processing wafers and factor $B$ consisting of $B O=$ adding $0 \%$ tapioca starch; $B 1=$ addition of $5 \%$ tapioca starch; and B2 =

\section{PENDAHULUAN}

Daun pepaya (Carica papaya L.) merupakan salah satu limbah pertanian, yang kandungan nutrisinya cukup tinggi. Daun pepaya cukup baik digunakan sebagai pakan karena mengandung protein kasar 13,5\%; serat kasar 14,68\%; lemak kasar 12,80\%; dan abu 14,4\% (Siti et al., 2016). Widjastuti (2009) menyatakan daun pepaya (Carica papaya) mengandung protein kasar mencapai 20,88\% sehingga berpotensi dimanfaatkan sebagai pakan sumber protein untuk menunjang produktivitas ternak.

Potensi nutrisi yang tinggi ini ternyata tidak didukung dengan peningkatan kecernaan protein dan keawetan daun pepaya bila disimpan dalam waktu lama sehingga perlu adanya pengolahan awal berupa teknologi silase dan amoniasi. Silase adalah teknik pengolahan pakan yang dapat meningkatkan kualitas daya simpan pakan. Silase merupakan teknik mengubah struktur bahan pakan dengan penambahan asam maupun penggunaan mikroba. Penggunaan teknik ini mampu meningkatkan nilai kecernaan bahan terutama kecernaan protein (Goddard \& Perret, 2005) sedangkan amoniasi dapat meningkatkan kandungan protein kasar (Nguyen addition of $10 \%$ tapioca starch. Observed parameters include color, aroma, texture, water absorption and density. The results showed that there was no interaction $(P>0.05)$ between the papaya leaf processing technique with different levels of tapioca starch on color, texture, aroma, water absorption and density. Papaya leaves are processed with different techniques provide a significant effect $(P<0.01)$ for color, texture, and aroma.. The use of different levels of tapioca starch in making complete rations had a significant effect $(P<0.01)$ on color. The use of papaya leaf ammoniation in the ration complete with tapioca starch 5\% level gives the best results judged by the color is dark brown color and give it a score of 3.03.

et al., 2001; Granzin \& Dryden, 2003), sehingga ketersediaan nitrogen untuk pertumbuhan mikroba menjadi lebih baik.

Pengolahan daun pepaya dengan silase dan amoniasi memiliki beberapa kelemahan diantaranya bahan pakan yang dihasilkan masih memiliki kadar air cukup tinggi yaitu 60 - $70 \%$, berpotensi muncul jamur sehingga mengurangi kualitas silase dan amoniasi tersebut, selanjutnya proses silase dan amoniasi umumnya menggunakan bahan tunggal sehingga tingkat kecukupan nutrisi yang diberikan biasanya masih dibawah standar kebutuhan nutrisi ternak ruminansia.

Oleh karena itu, perlu teknologi pengolahan lanjutan untuk meningkatkan tingkat keawetan dan nilai nutrisi daun pepaya tersebut karena menggunakan berbagai bahan baku. Teknologi tersebut dikenal dengan nama wafer. Wafer merupakan salah satu teknologi pengolahan pakan yang efektif dan diharapkan dapat menjaga kontiniutas pakan ternak, terutama pada musim kemarau dan memiliki bentuk fisik yang padat dan kompak berbentuk persegi yang sangat memudahkan dalam penyimpanan dan penanganan. Keuntungan pengolahan pakan 
menjadi wafer diantaranya akan meningkatkan kerapatan, mengurangi tempat penyimpanan, menekan biaya transportasi, memudahkan untuk mengontrol, memonitor, dan mengatur feed intake ternak, kandungan nutrien yang konsisten dan terjamin, mengurangi debu dan masalah pernafasan pada ternak (Sabri et al., 2017). Kualitas fisik wafer sangat didukung dengan bahan perekat. Bahan perekat adalah bahan tambahan yang sengaja ditambahkan ke dalam formulasi bahan pakan untuk menyatukan semua bahan baku yang digunakan (Saade dan Aslamyah, 2009). Beberapa bahan alami yang sudah digunakan antara lain tepung terigu, tepung jagung, tepung beras, onggok (Retnani et al., 2010; Setiyatwan et al., 2008).

Beberapa penelitian menyebutkan bahwa bahan alternatif yang dapat digunakan sebagai bahan perekat, tapioka mengandung karbohidrat sebesar 86,9\% (Sandi et al., 2015), selanjutnya penggunaan tepung tapioka 5\% dalam ransum menghasilkan sifat fisik terbaik dibandingkan tepung gaplek 5\% (Syamsu et al., 2007). Beradasarkan pemaparan diatas telah dilakukan penelitian tentang kualitas fisik wafer dengan penambahan berbagai level tepung tapioka serta tepung daun pepaya (Carica Papaya. L) yang diolah dengan teknik berbeda.

\section{METODE}

Bahan utama yang digunakan adalah daun pepaya. Molases dan urea diperoleh dari tempat penjualan pakan dan pertanian di Pekanbaru. Bahan pembuatan wafer adalah tepung silase daun pepaya dan tepung amoniasi daun pepaya, jagung halus, rumput lapang, dedak padi, ampas tahu. Selanjutnya bahan perekat wafer yaitu: tepung tapioka $0 \%, 5 \%$, dan 10\%. Alat yang digunakan Alat yang digunakan pada penelitian ini adalah gelas ukur, spatula, timbangan analitik, baskom, lakban dan silo (plastik). Alat yang digunakan untuk keperluan pembuatan wafer adalah grinding (hammer mill), mesin kempa wafer (suhu $150^{\circ}$, tekanan $200 \mathrm{~kg} / \mathrm{cm}^{3}$ selama 15 menit)

\section{Prosedur Penelitian}

Pelaksanaan penelitian ini terdiri dari beberapa tahap yaitu:

1. Pengolahan daun pepaya (Carica papaya. L.)

a. Daun pepaya dicacah lalu dikeringkan sampai kadar air 30-40\%, selanjutnya diberi tambahan bahan aditif molases 5\% dan disilase selama 21 hari, kemudian dikeringkan dan digiling menjadi tepung.

b. Daun pepaya dicacah lalu dikeringkan sampai kadar air 30-40\%, selanjutnya diberi tambahan bahan aditif urea 5\%, menggunakan cara basah yaitu dengan melarutkan urea kedalam air kemudian baru dicampurkan dengan daun pepaya dan disilase selama 21 hari, kemudian dikeringkan dan digiling menjadi tepung.

2. Pembuatan Bahan Ransum komplit

Bahan pembuatan wafer ransum komplit wafer terdiri dari daun pepaya dengan teknik pengolahan berbeda $5 \%$, rumput lapangan $26 \%$, dedak jagung $23 \%$, ampas tahu $23 \%$, dan level tepung tapiokayang berbeda yaitu $0 \%, 5 \%$ dan $10 \%$. Selanjutnya bahan digiling hingga berbentuk tepung (mash) menggunakan alat grinding. Kemudian dilakukan penimbangan sesuai dengan kebutuhan perlakuan, setelah itu bahan dicampurkan hingga homogen. 
3. Tahap Pembuatan Wafer

Setelah bahan tercampur secara homogen, wafer yang telah rata dimasukkan ke dalam cetakan yang ada pada mesin wafer. Mesin wafer berkapasitas 25 cetakan wafer dengan berat awal 35-40 g dan berat akhir $25 \mathrm{~g}$ per cetakan yang dihasilkan setelah dipress. Selanjutnya dilakukan pengepressan pada suhu $150^{\circ} \mathrm{C}$ dengan tekanan $200 \mathrm{~kg} / \mathrm{cm}^{3}$ selama $\pm 10-15$ menit. Kemudian dilakukan pengamatan sifat fisik wafer ransum komplit.

\section{Analisis Fisik}

Setelah pembuatan wafer berlangsung, kemudian dianalisis fisik (tekstur, warna, aroma, kerapatan, dan daya serap air) Pada analisis fisik warna dan tekstur yang akan dilakukan oleh 50 panelis tidak terlatih, yaitu panelis yang memiliki tingkat kemampuan rata-rata dan tidak mendapatkan pelatihan secara formal

\section{Metode Penelitian}

Penelitian ini menggunakan metode eksperimen dengan Rancangan Acak Lengkap
Pola Faktorial $(2 \times 3)$ dan 5 ulangan. Faktor perlakuan sebagai berikut:

Faktor A adalah Teknik Pengolahan Pakan dengan perlakuan:

A0 $=$ Wafer berbahan silase daun pepaya

A1 = Wafer berbahan amoniasi daun pepaya

Pengolahan silase daun pepaya berdasarkan Ardani (2018), dan pengolahan amoniasi daun pepaya berdasarkan Harahap dkk (2015.

Faktor B adalah Level penambahan tepung tapioka dengan perlakuan:

B0 $=$ Penambahan $0 \%$ tepung tapioka

$\mathrm{B} 1=$ Penambahan $5 \%$ tepung tapioka

$\mathrm{B} 2=$ Penambahan $10 \%$ tepung tapioka

Penambahan level tepung tapioka dengan taraf 5\% merupakan pemberian terbaik dari penelitian Retnani et al., (2010). Kandungan nutrisi bahan pakan dan formulasi ransum penelitian dapat dilihat pada Tabel 1,2 dan 3.

Tabel 1. Kebutuhan Nutrisi Ternak Sapi Bali Penggemukan

\begin{tabular}{ccc}
\hline TDN $(\%)$ & SK $(\%)$ & PK $(\%)$ \\
\hline $62-66$ & $17-18$ & $12-13$
\end{tabular}

Sumber : Wahyono dan Hardianto (2004)

Tabel 2. Kandungan Nutrisi Bahan Pakan Penyusun Wafer

\begin{tabular}{lccc}
\hline \multicolumn{1}{c}{ Bahan Baku } & \multicolumn{3}{c}{ Kandungan Bahan pakan(\%) } \\
\hline Rumput Lapangan* & 56,20 & 32,55 & PK \\
Dedak padi* & 55,90 & 21,57 & 6,95 \\
Dedak jagung* & 80,80 & 2,08 & 8,58 \\
Ampas tahu* & 77,90 & 19,00 & 8,48 \\
Daun Pepaya** & 72,93 & 11,05 & 30,30 \\
Daun pepaya silase** & 67,32 & 15,49 & 22,63 \\
Daun pepaya amoniasi ** & 69,61 & 14,53 & 14,55 \\
\end{tabular}

Sumber:* Departemen Nutrisi dan Teknologi Pakan Fakultas Peternakan IPB, 2015 ** Laboratorium Analisis Hasil Pertanian, Universitas Riau, 2019 
Tabel 3. Formulasi Kebutuhan Ransum Penelitian

\begin{tabular}{|c|c|}
\hline 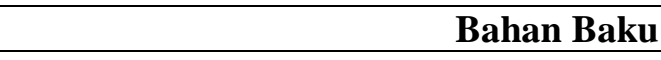 & Formulasi (\%) \\
\hline Rumput Lapangan & 26,00 \\
\hline Dedak Padi & 23,00 \\
\hline Dedak Jagung & 23,00 \\
\hline Ampas Tahu & 23,00 \\
\hline Tepung Daun Pepaya Silase, Amoniasi & 5,00 \\
\hline Total & 100 \\
\hline TDN & 66,93 \\
\hline SK & 18,83 \\
\hline PK & 13,83 \\
\hline
\end{tabular}

Keterangan disusun Berdasarkan Tabel 1 dan 2.

Peubah Penelitian

Penentuan Tekstur, Warna dan Aroma (Solihin et al., 2015)

Kualitas sifat wafer meliputi warna, aroma, tekstur, berat jenis, kerapatan, dan daya serap air. Penilaian terhadap warna didasarkan pada tingkat kegelapan wafer. Penilaian tekstur dilakukan dengan meraba tekstur wafer, kemudian indra penciuman digunakan untuk menilai aroma wafer. Penilaian pada wafer ini dilakukan oleh 50 panelis tidak terlatih, yaitu panelis yang memiliki tingkat kemampuan rata-rata dan tidak mendapatkan pelatihan secara formal.

Pengamatan sifat fisik dilakukan dengan membuat skor untuk setiap kriteria wafer, dapat dilihat pada Tabel 4.

Tabel 4. Nilai untuk Kriteria Wafer

\begin{tabular}{clrl}
\hline Kriteria & \multicolumn{1}{c}{ Karakteristik } & Skor & \multicolumn{1}{c}{ Keterangan } \\
\hline Warna & Coklat tua/hitam & $3-3,9$ & Sangat baik \\
& Coklat muda & $2-2,9$ & Baik \\
& Coklat berbintik putih & $1-1,9$ & Cukup \\
\multirow{2}{*}{ Aroma } & Khas Wafer & $3-3,9$ & Sangat baik \\
& Tidak berbau & $2-2,9$ & Baik \\
& Tengik & $1-1,9$ & Cukup \\
\multirow{2}{*}{ Tekstur } & Memiliki tekstur kasar, padat (tidak mudah pecah) dan tidak & $3-3,9$ & Sangat baik \\
& berlendir & & \\
& Memiliki tekstur kesat, mudah pecah dan tidak berlendir & $2-2,9$ & Baik \\
& Memiliki tekstur basah, mudah pecah dan berlendir & $1-1,9$ & Cukup
\end{tabular}

Sumber : (Solihin et al., 2015). 
Daya Serap Air (Trisyulianti et al., 2003)

Daya serap air diperoleh dari pengukuran berat wafer sebelum dan sesudah direndam dengan air selama 5 menit. Persentase daya serap air diperoleh dengan rumus:

$$
\operatorname{DSA}(\%)=\frac{\mathrm{B} 2-\mathrm{B} 1 \times 100 \%}{\mathrm{~B} 1}
$$

Keterangan:

DSA = daya serap air

B1 = berat awal

B2 = berak akhir

\section{Kerapatan (Trisyulianti et al., 2003)}

Nilai kerapatan wafer dapat dihitung dengan rumus :

$$
\begin{aligned}
\mathrm{K} & =\frac{\mathrm{W}}{(\mathrm{P} \times \mathrm{T} \times \mathrm{L})} \\
\mathrm{K} & =\operatorname{kerapatan}\left(\mathrm{g} / \mathrm{cm}^{2}\right) \\
\mathrm{W} & =\text { berat uji contoh }(\mathrm{g}) \\
\mathrm{P} & =\text { panjang contoh uji }(\mathrm{cm})
\end{aligned}
$$

$\mathrm{L} \quad=$ lebar contoh uji $(\mathrm{cm})$

$\mathrm{T} \quad=$ tebal contoh uji $(\mathrm{cm})$

\section{Analisis Data}

Rancangan yang akan digunakan dalam penelitian ini adalah rancangan acak lengkap pola faktorial $(2 \times 3)$ dengan 5 ulangan (Steel dan Torrie, 1993). Model matematika dari rancangan ini adalah:

$$
\mathrm{Y}_{\mathrm{ijk}}=\mu+\alpha_{\mathrm{i}}+\beta_{\mathrm{j}}+(\alpha \beta)_{\mathrm{ij}}+\varepsilon_{\mathrm{ijk}}
$$

Jika hasil yang diperoleh menunjukkan berbeda nyata atau sangat nyata, maka dilakukan uji lanjut Duncan's Multiple Range Test

\section{HASIL DAN PEMBAHASAN}

\section{Warna Wafer}

Rataan skor warna wafer ransum komplit sapi melalui penambahan tepung daun pepaya dengan teknik pengolahan dan level tepung tapioka yang berbeda dapat dilihat pada Tabel 5 .

Tabel 5. Nilai Rataan Warna Wafer

\begin{tabular}{cccccc}
\hline Faktor A & \multicolumn{2}{c}{ Faktor B Level Tepung Tapioka } & Rataan & Ket. \\
\cline { 2 - 4 } Pengolahan Pakan & $0 \%$ & $5 \%$ & $10 \%$ & & \\
\hline Silase & $2,78 \pm 0,09$ & $2,86 \pm 0,07$ & $2,92 \pm 0,02$ & $2,85 \pm 0,09^{\mathrm{a}}$ & $\begin{array}{c}\text { Coklat } \\
\text { Tua } \\
\text { Amoniasi }\end{array}$ \\
& $3,01 \pm 0,02$ & $3,02 \pm 0,05$ & $3,07 \pm 0,04$ & $3,03 \pm 0,04^{\mathrm{b}}$ & $\begin{array}{c}\text { Coklat } \\
\text { Tua }\end{array}$ \\
\hline Rataan & $2,89 \pm 0,05^{\mathrm{A}}$ & $2,94 \pm 0,01^{\mathrm{AB}}$ & $2,99 \pm 0,01^{\mathrm{B}}$ & & \\
\hline
\end{tabular}

Keterangan : Superskrip yang berbeda pada kolom (huruf kecil) dan baris (huruf besar) yang sama menunjukkan perbedaan sangat nyata $(\mathrm{P}<0,01), \pm$ : menyatakan standar deviasi.

Tabel 5 menunjukkan teknik pengolahan pakan dan level tepung tapioka yang berbedan berpengaruh sangat nyata $(\mathrm{P}<0,01)$ terhadap kualitas fisik wafer ransum komplit. Tidak terjadi interaksi $(\mathrm{P}>0,05)$ antara teknik pengolahan pakan dengan level tepung tapioka terhadap kualitas fisik wafer ransum komplit.
Tabel 5 menunjukkan wafer yang berasal amoniasi memiliki rataan warna yang lebih tinggi yaitu 3,03 dibandingkan produk wafer dari silase dengan skor 2,85 , tetapi secara penilaian organoleptik menghasilkan warna yang sama yaitu coklat tua. Hal ini diduga karena perubahan warna ini dapat terjadi karena adanya proses penguraian bahan organik selama proses 
fermentasi. Fermentasi dapat menguraikan bahan organik yang kompleks menjadi lebih sederhana dengan adanya aktivitas dari mikroorganisme. Perubahan warna coklat tua disebabkan karena proses pemanasan wafer dengan suhu yang tinggi didukung dengan bahan penyusun ransum untuk pembuatan wafer yang relatif sama.

Warna tersebut terjadi karena adanya proses maillard atau browning reaction sebagai akibat panas yang berlebihan. Warna wafer merupakan hasil reaksi karbohidrat (reaksi maillard), khususnya gula pereduksi dengan gugus amino primer yang menghasilkan senyawa melanoidin sehingga warna wafer akan menjadi coklat (Kardina, 2019). Lamid et al. (2016) menyatakan warna fermentasi hay atau hijauan kering yang baik yaitu coklat.

Perbedaan level tepung tapioka memberikan pengaruh sangat nyata $(\mathrm{P}<0,01)$ terhadap warna wafer yang dihasilkan. Pada perlakuan level tepung tapioka berkisar 2,89;
2,94 dan 2,99. Hal ini diduga pada perlakuan B1 (penambahan 5\% tepung tapioka) semakin tinggi level tepung tapioka maka kemampuan mengikat sumber bahan pakan berbentuk kering juga semakin baik. Pada perlakuan B0 dan B1 memiliki nilai relatif sama yaitu coklat tua. Hal ini sesuai dengan penelitian Retnani dkk (2020) menambahkan pati dengan kadar amilosa tinggi mempunyai kekuatan hidrogen yang lebih besar karena jumlah rantai lurus yang besar dalam granula, sedangkan amilopektin memengaruhi bentukan daya lengket yang kuat dan pembentukan sifat kekenyalan, pati yang biasa digunakan dalam pembuatan wafer adalah pollard, dedak padi, onggok, dan jagung.

\section{Tekstur}

Rataan skor tekstur wafer ransum komplit sapi melalui penambahan tepung daun pepaya dengan teknik pengolahan dan level tepung tapioka yang berbeda dapat dilihat pada Tabel 6.

Tabel 6. Nilai Rataan Tekstur Wafer

\begin{tabular}{|c|c|c|c|c|c|}
\hline \multirow{2}{*}{$\begin{array}{c}\text { Faktor A } \\
\text { Pengolahan Pakan }\end{array}$} & \multicolumn{3}{|c|}{ Faktor B Level Tepung Tapioka } & \multirow{2}{*}{ Rataan } & \multirow{2}{*}{ Ket. } \\
\hline & $0 \%$ & $5 \%$ & $10 \%$ & & \\
\hline Silase & $2,94 \pm 0,09$ & $3,04 \pm 0,08$ & $3,05 \pm 0,08$ & $3,01 \pm 0,09^{\mathrm{a}}$ & $\begin{array}{c}\text { Tekstur kesat } \\
\text { dan mudah pecah }\end{array}$ \\
\hline Amoniasi & $3,15 \pm 0,04$ & $3,16 \pm 0,02$ & $3,15 \pm 0,04$ & $3,15 \pm 0,03^{\mathrm{b}}$ & $\begin{array}{c}\text { Tekstur kesat } \\
\text { dan mudah pecah }\end{array}$ \\
\hline Rataan & $3,05 \pm 0,04$ & $3,10 \pm 0,04$ & $3,10 \pm 0,03$ & & - \\
\hline
\end{tabular}

Keterangan : Superskrip yang berbeda pada kolom (huruf kecil) yang sama menunjukkan perbedaan sangat nyata $(\mathrm{P}<0,01), \pm$ : menyatakan standar deviasi.

Tabel 6 menunjukkan teknik pengolahan pakan (amoniasi dan silase) berpengaruh sangat nyata $(\mathrm{P}<0,01)$ terhadap kualitas fisik wafer ransum komplit melalui penambahan tepung daun pepaya, sedangkan level tepung tapioka yang berbeda tidak berpengaruh nyata $(\mathrm{P}>0,05)$ terhadap tekstur. Tidak terjadi interaksi $(\mathrm{P}>0,05)$ antara teknik pengolahan pakan dengan level tepung tapioka terhadap kualitas fisik wafer ransum komplit sapi melalui penambahan tepung daun pepaya.

Pengolahan amoniasi memiliki rataan tekstur tertiggi yaitu 3,16 dibandingkan $(\mathrm{P}<0,01)$ dengan pengolahan silase 3,01. Penilaian tekstur dengan menilai tekstur wafer yang kesat dan mudah pecah. Hal ini diduga karena pada teknik 
pengolahan pakan amoniasi terjadinya perenggangan ikatan lignin dengan selulosa dan hemiselulosa sehingga dihasilkan tekstur kesat dan mudah pecah. Hal ini sesuai dengan penelitian Utomo (2015) yang menyatakan bahwa fermentasi yang baik menghasilkan tekstur yang tidak menggumpal dan tidak berlendir. Candrasari et al., (2011) menyatakan tekstur hasil fermentasi yang lebih lunak dapat disebabkan karena adanya proses pelonggaran ikatan antara lignin dan selulosa akibat proses penambahan urea dan adanya penguraian bahan organik dari yang kompleks menjadi lebih sederhana akibat akibat adanya proses fermentasi. Tekstur berubah menjadi lebih lembut akibat penambahan urea dan proses fermentasi (Fitria \& Candrasari, 2019).

Tabel 7. Nilai Rataan Aroma Wafer
Perbedaan level tepung tapioka pada wafer ransum komplit sapi tidak berpengaruh nyata $(\mathrm{P}>0,05)$ terhadap tekstur wafer yang dihasilkan. Hal ini diduga karena level tepung tapioka yang digunakan hanya mempengaruhi pengikatan komponen-komponen bahan pakan dari wafer yang akan mempengaruhi kepada kekompakan dan kerapatan wafer yang dihasilkan. Menurut Jayusmar (2000). Kerapatan wafer yang rendah akan memperlihatkan bentuk wafer pakan tidak terlalu padat dan tekstur yang lebih lunak serta porous (berongga)

\section{Aroma}

Rataan skor aroma wafer ransum komplit melalui teknik pengolahan dan level tepung tapioka yang berbeda dapat dilihat pada Tabel 7 .

\begin{tabular}{cccccc}
\hline $\begin{array}{c}\text { Faktor A } \\
\text { Pengolahan Pakan }\end{array}$ & \multicolumn{2}{c}{ Faktor B Level Tepung Tapioka } & \multirow{2}{*}{ Rataan } & Keterangan \\
\cline { 2 - 4 } Silase & $3,01 \pm 0,05$ & $3,07 \pm 0,05$ & $3,12 \pm 0,08$ & $3,07 \pm 0,07^{\mathrm{a}}$ & $\begin{array}{c}\text { Harum khas } \\
\text { wafer/ } \\
\text { karamel } \\
\text { Amoniasi }\end{array}$ \\
\hline Rataan & $3,14 \pm 0,03$ & $3,19 \pm 0,05$ & $3,13 \pm 0,09$ & $3,19 \pm 0,06^{\mathrm{b}}$ & $\begin{array}{c}\text { Harum khas } \\
\text { wafer/ } \\
\text { Karamel }\end{array}$ \\
\hline
\end{tabular}

Keterangan : Superskrip yang berbeda pada kolom (huruf kecil) yang sama menunjukkan perbedaan sangat nyata $(\mathrm{P}<0,01) \pm$ : menyatakan standar deviasi.

Tabel 7 menunjukan teknik pengolahan pakan berpengaruh sangat nyata $(\mathrm{P}<0,01)$ terhadap kualitas fisik wafer ransum komplit sedangkan level tepung tapioka yang berbeda tidak berpengaruh nyata $(\mathrm{P}>0,05)$ terhadap aroma. Tidak terjadi interaksi $(\mathrm{P}>0,05)$ antara teknik pengolahan pakan dengan level tepung tapioka terhadap kualitas fisik wafer ransum komplit.
Pengolahan dengan teknik amoniasi memiliki rataan aroma tertinggi dengan skor 3,19 dibandingkan pengolahan dengan teknik silase dengan skor 3,07 yang menghasilkan aroma harum khas wafer/karamel. Hal ini diduga karena aroma yang dihasilkan dari teknik amoniasi sangat erat kaitan nya terhadap penambahan urea. Pemberian urea tersebut memberikan suasana basa. Hal ini sesuai dengan Febrina et al (2020) 
bahwa urea mengalami proses hidrolisis menjadi $\mathrm{NH}_{3}$ dan $\mathrm{CO}_{2}, \mathrm{NH}_{3}$ bersama dengan $\mathrm{H}_{2} \mathrm{O}$ membentuk $\mathrm{NH}_{4} \mathrm{OH}$ yang bersifat basa. Pada teknik silase aroma yang dihasilkan dari penambahan molases, pemberian molases tersebut memberikan proses fermentasi. Aroma wangi dari proses fermentasi disebabkan bakteri asam laktat mempunyai kemampuan mengubah berbagai senyawa yang terdapat pada media menjadi senyawa lain yang lebih sederhana, memberikan flavor dan aroma yang khas fermentasi pada pakan (Candrasari et al., 2019)

Perbedaan level tepung tapioka pada wafer tidak berpengaruh nyata $(\mathrm{P}>0,05)$ terhadap aroma wafer ransum komplit. Hal ini diduga aroma wafer dipengaruhi oleh komposisi dan jenis limbah yang digunakan sebagai bahan pembuatan wafer. Aroma wafer berasal dari proses pemanasan bahan - bahan wafer yang terdiri dari limbah dan juga beberapa bahan yang mengandung pati, serta bahan perekat yang memperkuat aroma asal wafer yaitu khas karamel. Hal ini diduga aroma wafer dipengaruhi oleh komposisi dan jenis limbah yang digunakan sebagai bahan pembuatan wafer. Aroma wafer berasal dari proses pemanasan bahan - bahan wafer yang terdiri dari limbah dan juga beberapa bahan yang mengandung pati, serta bahan perekat yang memperkuat aroma asal wafer yaitu khas karamel. Hal ini sesuai pendapat Wati dkk (2020) selain pemanasan bahan pakan, molases dan ubi kayu yang menyumbangkan aroma wangi karena adanya kandungan gula, sehingga aroma yang ditimbulkan umumnya wangi seperti karamel sebagai akibat dari reaksi tersebut.

\section{Kerapatan}

Rataan skor kerapatan wafer ransum komplit dengan teknik pengolahan dan level tepung tapioka yang berbeda dapat dilihat pada Tabel 8.

Tabel 8. Nilai Rataan Kerapatan Wafer Ransum Komplit

\begin{tabular}{cccccc}
\hline Faktor A & \multicolumn{3}{c}{ Faktor B Level Tepung Tapioka } & \multirow{2}{*}{ Rataan } & \multirow{2}{*}{ Ket. } \\
\cline { 2 - 4 } Pengolahan Pakan & $0 \%$ & $5 \%$ & $10 \%$ & & \\
\hline Silase & $0,48 \pm 0,05$ & $0,44 \pm 0,06$ & $0,43 \pm 0,04$ & $0,45 \pm 0,05$ & Rapat \\
Amoniasi & $0,40 \pm 0,08$ & $0,44 \pm 0,02$ & $0,47 \pm 0,05$ & $0,44 \pm 0,06$ & Rapat \\
\hline Rataan & $0,44 \pm 0,03$ & $0,44 \pm 0,03$ & $0,45 \pm 0,01$ & & \\
\hline
\end{tabular}

Tabel 8 menunjukan masing-masing faktor teknik pengolahan daun pepaya dan level tepung tapioka yang berbeda tidak berpengaruh nyata $(\mathrm{P}>0,05)$ terhadap kualitas fisik wafer ransum komplit. Tidak terjadi interaksi $(\mathrm{P}>0,05)$ antara teknik pengolahan daun pepaya dengan level tepung tapioka terhadap kualitas fisik wafer ransum komplit.

Teknik pengolahan pakan tepung daun pepaya baik silase dan amoniasi berbentuk wafer menghasilkan kerapatan partikel yang tidak berbeda $(\mathrm{P}>0,05)$ pada semua perlakuan memiliki nilai berkisar $0,44-0,45 \mathrm{~g} / \mathrm{cm}^{-3}$. Hal ini diduga karena produk wafer baik pada perlakuan silase dan amoniasi memiliki tekstur yang masih rapat, sehingga nilai kerapatan yang dihasilkan juga sama. Hal ini sesuai dengan Jayusmar (2000), menyatakan kerapatan wafer yang rendah akan memperlihatkan bentuk wafer pakan tidak terlalu padat dan tekstur yang lebih lunak serta 
berongga. Nilai rataan kerapatan wafer berkisar $0,40-0,48 \mathrm{~g} / \mathrm{cm}^{-3}$.

Perbedaan level tepung tapioka yang digunakan pada wafer tidak berpengaruh nyata $(\mathrm{P}>0,05)$ terhadap kerapatan wafer ransum komplit. Hal ini diduga karena bahan perekat yang digunakan memiliki karbohidrat tinggi sehingga memiliki tekstur yang padat dan kerapatan yang baik. Hal ini sesuai dengan pernyataan Jayusmar (2000), faktor yang mempengaruhi kerapatan wafer yaitu penggunaan limbah agroindustri (hasil ikutan pertanian), jenis mesin pengempa dan tingkat pemadatan

hamparan

selama

proses

pengempaan.

Nilai kerapatan partikel wafer pada penelitian ini berkisar $0,40-0,48 \mathrm{~g} / \mathrm{cm}^{-3}$. Hasil penelitian ini masih lebih rendah dibandingkan Jayusmar (2000) yang menyebutkan bahwa kerapatan yang bagus bernilai $0,69 \mathrm{~g} / \mathrm{cm}^{-3}$.

\section{Daya Serap Air}

Rataan skor daya serap air wafer ransum komplit sapi melalui penambahan tepung daun pepaya dengan teknik pengolahan dan level tepung tapioka yang berbeda dapat dilihat pada Tabel 9 .

Tabel 9. Nilai Rataan Daya Serap Air Wafer

\begin{tabular}{ccccc}
\hline Faktor A & \multicolumn{3}{c}{ Faktor B Level Tepung Tapioka } & \multirow{2}{*}{ Rataan } \\
\cline { 2 - 4 } Pengolahan Pakan & $0 \%$ & $5 \%$ & $10 \%$ & \\
\hline Silase & $51,60 \pm 8,38$ & $56,00 \pm 4,18$ & $55,00 \pm 3,81$ & $54,20 \pm 5,75$ \\
Amoniasi & $54,00 \pm 5,43$ & $54,80 \pm 3,90$ & $46,40 \pm 6,19$ & $51,73 \pm 6,25$ \\
\hline Rataan & $52,80 \pm 2,09$ & $55,40 \pm 0,20$ & $50,70 \pm 1,68$ & \\
\hline
\end{tabular}

Tabel 9 menunjukan teknik pengolahan pakan dan level tepung tapioka tidak berpengaruh nyata $(\mathrm{P}>0,05)$ terhadap kualitas fisik wafer ransum komplit sapi melalui penambahan tepung daun pepaya. Tidak terjadi interaksi $(\mathrm{P}>0,05)$ antara teknik pengolahan pakan dengan level tepung tapioka terhadap kualitas fisik wafer ransum komplit sapi melalui penambahan tepung daun pepaya.

Teknik pengolahan pakan tepung daun pepaya pada semua perlakuan memiliki nilai berkisar 54,20\% dan 51,73\%. Pengolahan daun pepaya dengan teknik yang berbeda tidak berpengaruh nyata $(\mathrm{P}>0,05)$ terhadap daya serap air. Hal ini sudah ada bahwa wafer silase dan amoniasi daun pepaya memiliki kerapatan yang hampir sama yaitu masih tergolong rapat, kerapatan ini dipengaruhi besar bahan penyusun dan ikatan partikel.

Perbedaan level tepung tapioka yang digunakan pada pembuatan wafer ransum komplit tidak berpengaruh nyata $(\mathrm{P}>0,05)$ terhadap daya serap air wafer ransum komplit. Hal ini diduga karena kemampuan untuk meyerap air di sekelilingnya untuk memberikan ikatan dengan partikel bahan dengan baik. Hal ini sesuai dengan Trisyulianti et al (2003), kadar air yang tinggi mengindikasikan bahwa molekul air yang berikatan dengan partikel penyusun ransum komplit semakin banyak, sehingga saat direndam dalam air selama 5 menit, nilai daya serap airnya menurun. Semakin tinggi nilai kerapatan wafer maka semakin rendah nilai daya serap air wafer (Syahri et al., 2018). Krisnan \& Ginting (2009), menyatakan bahwa daya serap air yang rendah 
akan menyulitkan dalam pengahancuran bahan atau wafer oleh saliva pada saat dikonsumsi oleh ternak ruminansia, akan tetapi daya serap air yang terlalu tinggi juga akan menyebabkan wafer tidak akan tahan lama untuk disimpan.

\section{KESIMPULAN DAN SARAN}

Wafer ransum komplit berbahan daun pepaya amoniasi dan penggunaan 5\% tepung tapioka menghasilkan kualitas fisik terbaik dinilai dari warna. Saran dari hasil penelitian ini adalah perlu dilakukan pengujian secara in vitro pada ternak ruminansia untuk melihat pengaruh wafer berbahan tepung amoniasi daun pepaya terhadap fermentasi rumen

\section{DAFTAR PUSTAKA}

Ardani, V. (2018). Kualitas Nutrisi Silase Daun Indigofera (Indigofera $s p$ ), Daun Pepaya (Carica papaya L), dan Daun Kelor (Moringa oleifera) sebagai Bahan Pakan. Skiripsi. Fakultas Peternakan. Institut Pertanian Bogor. Bogor.

Candrasari, D. P., P. S. B. Subur \& Hari, H (2011). Perlakuan Kalsium Hidroksida Dan Urea Untuk Meningkatkan Kualitas Bagas Tebu. Buletin Peternakan. 35(3):165-172.

Fitria, R. \& Candrasari, D. P. (2019). Kualitas Fisik Amoniasi Fermentasi Janggel Jagung dengan Penambahan M21 Dekomposer pada Level yang Berbeda. Jurnal Ilmiah Ilmu Ilmu Peternakan. 22(2):117-123.

Febrina, D., N. Khairunnisa \& Febriyanti, R (2020). Pengaruh Lama Pemeraman dan Metode Pengolahan terhadap Kualitas Fisik dan Kandungan Nutrisi Jerami Jagung. Jurnal Agripet. 20(2): 160-167.

Goddard, J.S \& Perret J. S. M. (2005). Co-drying fish silage for use in aquafeeds. Animal Feed Science and Technology. $118: 337-342$.

Harahap, M.A., A. Subrata \& Ahcmadi. J. (2015). Fermentabilitas Pakan Berbasis Amoniasi Jerami Padi dengan sumber Protein yang
Diproteksi di dalam Rumen secara In Vitro. Animal Agriculture Journal. 4(1): 137-143.

Jayusmar. (2000). Pengaruh Suhu dan Tekanan Pengempaan terhadap Sifat Fisik Wafer Ransum Komplit dari Limbah Pertanian Sumber Serat dan Leguminosa Untuk Ternak Ruminansia. Skripsi. Fakultas Peternakan. Institut Pertanian Bogor, Bogor.

Kardina. (2019). Kualitas Fisik Wafer Ransum Komplit dengan Penambahan Tepung Inti Biji Karet (Hevea brasiliensis) dan Lama Penyimpanan yang Berbeda. Skripsi. Fakultas Pertanian dan Peternakan. Universitas Islam Negeri Suska Riau. Pekanbaru.

Krisnan, R \& Ginting, S.P. (2009). Penggunaan Solid Ex-Decanter sebagai Perekat Pembuatan Pakan Komplit Berbentuk Pellet: Evaluasi Fisik Pakan Komplit Berbentuk Pellet. Jurnal Teknologi dan Veteriner. 480-486.

Lamid, M,. R. S. Wahjuni \& Nurhajati. T. (2016). Ibm Pengolahan Silase Dari Hay (Haylase) Sebagai Bank Pakan Hijauan Dengan Konsentrat Untuk Penggemukan Sapi Potong Di Kecamatan Arosbaya Kabupaten Bangkalan-Madura. Agroveteriner. 5(1): 74-81.

Retnani, Y. Rahmayeni. H., \& Herawati, L. 2010. Uji Sifat Fisik RansumAyam Broiler Bentuk Pellet yangditambahkan Perekat Onggok Melalui Proses Penyemprotan Air. Agripet, 11(1):13-18.

Retnani, Y, N.N Barkah, A. Saenab \& Taryati. (2020). Teknologi Pengolahan Wafer Pakan untuk Meningkatkan Produksi dan Efisiensi Pakan. Wartazoa. 30(1): 37-50

Saade, E. \& Aslamyah, S. (2009). Uji Fisik dan Kimiawi Pakan Buatan Untuk Udang Windu (Panaeus monodon Fab) yang Menggunakan Berbagai Jenis Rumput Laut sebagai Bahan Perekat. Jurnal Ilmu Kelautan dan Perikanan. 19: 107-115.

Sabri, R., Kasmiran \& A. Fadli, C. (2017). Daya Simpan Wafer Dari Bahan Baku Lokal sebagai Bahan Pakan Ternak Ruminansia. 
Jurnal Edukasi Sains Biologi. 6(1): 35-40 Universitas Almuslim Bireuen.

Sandi, S., A.I. M. Ali \& Akbar, A.A. (2015). Uji In-Vitro Wafer Ransum Komplit dengan Bahan Perekat yang Berbeda. Jurnal Peternakan Sriwijaya. 4(2):7-16.

Setyatwan, H., D. Saefulhajar dan U. Hidayat. T. 2008. Pengaruh Bahan Perekat dan Lama Penyimpanan terhadap Sifat Fisik Ransum Bentuk Pelet. Jurnal Ilmu Ternak. 8(2): 105-108.

Siti, N W., N. M. S. Sukmawati., I N. Ardika., I N. Sumerta., N. M. Witariadi., N. N. Candraasih Kusumawati \& Roni, N.G.K (2016). Pemanfaatan Ekstrak Daun Pepaya Terfermentasi Untuk Meningkatkan Kualitas Daging Ayam Kampung. Majalah Ilmiah Peternakan. 19 (2): 51-55.

Solihin. (2015). Pengaruh Lama Penyimpanan terhadap Kadar Air, Kualitas Fisik, dan Sebaran Jamur Wafer Limbah Sayur dan Umbi - Umbian. Skripsi. Fakultas Pertanian Universitas Lampung. Bandar Lampung.

Steel, R.G.D \& Torrie, T.H. (1993). Prinsip dan Prosedur Statistika. Gramedia. Jakarta

Syahri, M., Retnani, Y., \& Khotijah, L. (2018). Evaluasi Penambahan Binder Berbeda terhadap Kualitas Fisik Mineral Wafer. Buletin Makanan Ternak. 16 (1).

Syamsu, J.A. (2007). Karakteristik Fisik Pakan Itik Bentuk Pelet yang diberi Bahan Perekat Berbeda dan Lama Penyimpanan yang Berbeda. Jurnal Ilmu Ternak. 7(2): 128134.

Trisyulianti, E., Suryahadi \& Rahkma, V.N. (2003). Pengaruh penggunaan molases dan tepung gaplek sebagai bahan perekat terhadap sifat fisik wafer ransum komplit. Media Peternakan. 26 (2): 35-39.

Utomo, R. (2015). Konservasi Hijauan Pakan dan Peningkatan Kualitas Bahan Pakan Berserat Tinggi. Yogyakarta: Gadjah Mada University Press.
Wahyono, D. E. \& Hardianto, R. (2004). Pemanfaatan Sumber Daya Pakan Lokal Untuk Pengembangan Usaha Sapi Potong. Grati. Pasuruan.

Wati, E. P. (2020). Uji Aktifitas Antibakteri Kombinasi Ekstrak Etanol Buah Mengkudu (Morina citrifolia Linn) dan Rimpang Jahe Merah (Zingiber officinale Rosc) terhadap Pertumbuhan E. coli secara in vitro. Skripsi. Fakultas Kedokteran Universitas Jember.

Widjastuti, T. (2009). Pemanfaatan tepung daun pepaya (Carica papaya. L L Ess) dalam upaya peningkatan produksi dan kualitas telur ayam Sentul. J. Agroland. 16 (3) : 268273. 